\title{
FEATURES OF PHENACITE MINERALIZATION FROM THE URAL EMERALD MINES
}

\author{
M. P. Popov, A. G. Nikolaev
}

\section{ОСОБЕННОСТИ ФЕНАКИТОВОЙ МИНЕРАИИЗАЦИИ С УРАИЬСКИХ ИЗУМРУАНЫХ КОПЕЙ}

\author{
М. П. Попов, А. Г. Николаев
}

Рассмотрены вопросы особенностей развития фенакитовой минераяизации на Изумрудных копях Урала, которая достаточно хорошо развита и описана на Мариинском (Мамышевском) и Сретенском (Сверловском) изумрудно-беримиевых месторожцениях. Фенакит широко распространен на многих беримиевых месторожлениях, но кристамы ювелирного качества, да еще таких крупных размеров, как на Изумрудных копях, образует редко. Несмотря на давность открытия (1833) и по причине редкой встречаемости ювелирного качества кристамлов и наяичия в месторождениях Изумрудных копей более Аорогих и ценных камней - изумрудов и александритов, фенакит остается до сих пор почти неизвестным на рынке Арагоценных камней и особенно за границей. Наиболее часто фенакитовая минерализация встречается в сююдитовых жилах, представленных серым и зеленовато-серым фрлогопитом. Характер распределения фенакита в слюдитовых жилах крайне неравномерный. Оруденение типично гнездовое. Высокое содержание фенакита отмечается в слюдитовых жилах, минеральный состав которых опрелеляется наличием в основной массе флогопита, прожилков и желваков беримийсодержашего маргарита (Ве-маргарит) и хлорита. Низкое содержание фенакита зафиксировано в сююдитовых жилах, в состав которых входят флогопит, плагиокиаз, берим, флюорит, дымчатый кварц. На Сретенском месторожцении встречена жила, которая относится к новому типу рудных тел хризоберим-сенакитового состава, залегаюших в ультраосновных породах. В отличие от изумрудоносных слюдитовых жил, имеюших северо-запанное простирание, хризоберим-фенакитовые рудные тела ориентированы в близширотном направлении и имеют северное пачение под углом $75^{\circ}-80^{\circ}$. Наиболее распространенный облик кристамов фенакита на Изумрудных копях - ромбоэмрический и короткостолбчатый. Кристамы характеризуются большим числом граней. Обычные формы - гексагональная призма с ромбоэдрами. $\triangle$ войники прорастания встречаются часто, характерны друзы, шестоватые агрегаты и сферолиты. По цвету фенакит может быть бесцветным или слабо окрашенным в винно-желтый, иногАа розоватый, светло-серый, белый, редко бурый цвет. Окраска в кристаме может распространяться неравномерно. Винно-желтая окраска неустойчива, на свету она полностью исчезает. Наиболее часто в фенаките в качестве вкиючений встречаются клинохиор, ильменит и пирротин. В работе приведены спектры инфракрасной и оптической спектроскопии Аля фенакитов различной окраски. Кроме того, показано сходство геммологических свойств уральских фенакитов и кристамами из Шри-Аанки.

Киючевые слова: Урац; изумрудно-беримиевые месторожцения; фенакит; кристам; геммологичекие характеристики; спектры отражения и поглощения.

The authors consider the problems of development of phenacite mineralization at the Ural Emerald Mines, which is rather well developed and described in the Mariinsky (Malyshevsky) and Sretensky (Sverdlovsk) emerald-beryllium deposits. Phenacite is widespread in many beryllium deposits, but crystals of jewelry quality, with such large sizes as at the Emerald Mines, form rarely. Despite the prescription of the discovery (1833), and because of the rare occurrence of jewelry quality of crystals, and the presence of more expensive and valuable stones - emeralds and alexandrites - in deposits of the Emerald mines, phenacite remains almost unknown in the precious stones market, and especially abroad. Phenacite mineralization mostly occurs in the micaceous veins represented by gray and greenish-gray phlogopite. Distribution of phenacite in the micaceous veins is extremely uneven. Mineralization is typically nesting. High content of phenacite appears in the micaceous veins, mineral composition of which is mostly phlogopite, veins and concretions of beryllium-containing margarite (B-margarite) and chlorite. Content of phenacite is low in the micaceous veins that include phlogopite, plagioclase, beryl, fluorite, smoky quartz. At the Sretensky deposit is located a vein that refers to a new type of ore bodies of the chrysoberyl-phenacite composition lying in ultrabasic rocks. Unlike emerald-bearing micaceous veins that have a northwestern spread, the chrysoberyl-phenacite ore bodies are oriented in the near-latitudinal direction and have a northern incidence at an angle of $75^{\circ}-80^{\circ}$. The most common form of phenacite crystals on the Emerald Mines is rhombohedral and short columned. Crystals have a large number of faces. The usual shapes are a hexagonal prism and rhombohedrons. Twin crystals are common, druses, columnar aggregates, and spherulites are characteristic. Phenacite can be colorless or slightly colored in wine yellow, sometimes pinkish, light gray, white, and rarely brown. The color in the crystal can spread non-uniformly. Wine-yellow coloration is not stable; it completely disappears in the light. Most common inclusions in phenacite are clinochlor, ilmenite and pyrrhotite. The work presents spectra of infrared and optical spectroscopy for phenacites of various colors. In addition, the authors show the similarity of gemological properties of the Ural phenacites and crystals from Sri Lanka.

Keywords: Ural; Emerald-beryllium deposits; phenacite; crystal; gemmological characteristics; reflection and absorption spectra.

\section{ntroduction}

Phenacite is the least studied, known and demanded stone, in comparison to its famous "brothers in the Emerald Mines" - emerald and alexandrite. Meanwhile, the Ural phenacite is now confidently making its way to the market of jewelry stones.

Phenacite is a beryllium mineral $\left(\mathrm{Be}_{2} \mathrm{SiO}_{4}\right)$. Ya. V. Kokovin discovered phenacite at the Emerald Mines at the Sretenskiy field of the Emerald Mines, and N. Nordensheld chemically determined it in
1833. It is widespread at beryllium deposits, but jewelry quality crystals of such large sizes as at the Emerald Mines are rare. For this reason phenacite as a gemstone is infamous in Europe. Despite the prescription of the discovery, because of the rare occurrence of jewelry quality of crystals, and due to the presence of more expensive and valuable stones in emerald mines - emeralds and alexandrites, phenacite to this day remains almost unknown on the jewel market, especially abroad. A. E. Fersman was the first one who drew serious attention to this rare stone, which undoubtedly has decorative properties - transparency and a very delicate yellowish or pinkish hue. Due to its excellent shine, it often passes off as topaz or even as a diamond. However, the color of phenacite is very unstable, and often, beautifully colored during mining, stone completely fades after a few months under the sunlight, what is one of its disadvantages [1].

Geology and location conditions

On the territory of the Ural emerald mines, phenacite mineralization is rather well developed and is described in the Mariinsky (Malyshevsky) and Sretensky (Sverdlovsk) emeraldberyllium deposits. According to the exploration results of the Mariinsky deposit, phenacite is extremely rare there. Phenacite mineralization mostly occurs in the micaceous veins represented by gray and greenish-gray phlogopite. Distribution of phenacite in the micaceous veins is extremely uneven. Mineralization is typically nesting. High content of phenacite appears in the micaceous veins, mineral composition of which is mostly phlogopite, veins and concretions of beryllium-containing margarite (B-margarite) and chlorite (Fig. 1). Content of phenacite is low in the micaceous veins that include phlogopite, plagioclase, beryl, fluorite, smoky quartz.

Sometimes phenacite crystals form together with emerald crystals (beryl) (Fig. 2).

One can observe both growth of emerald over phenacite and overgrowth of phenacite around beryl crystals (Fig. 3). In all cases, there are induction faces.

During exploration and development at the Sretensky deposit, a few phenacite crystals in the mica complexes were among the find- 


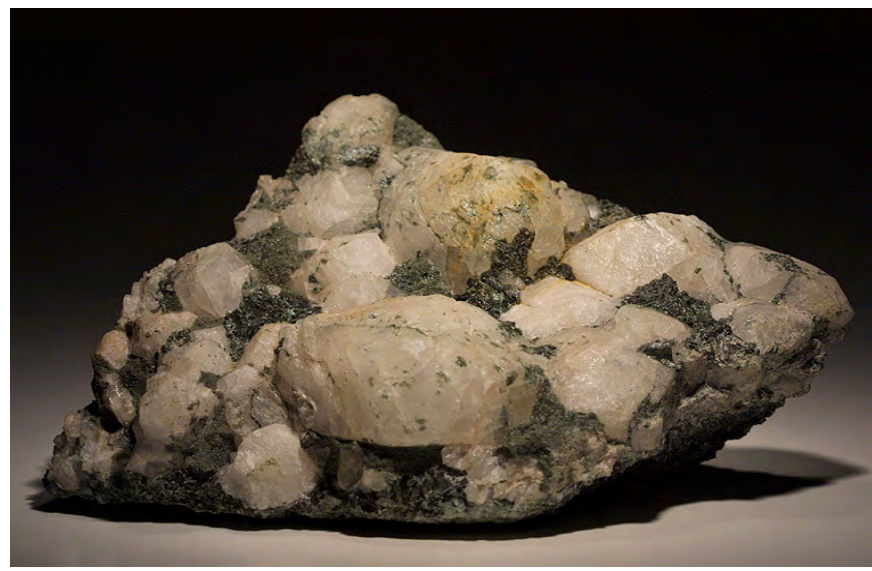

Figure 1. Druse of phenacite crystals with chlorite from micaceous complexes.

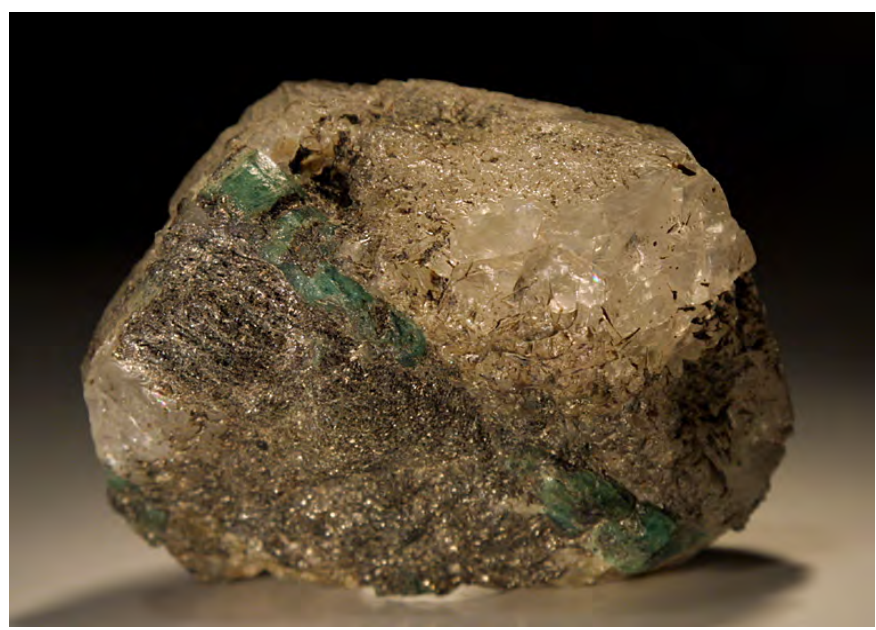

Figure 2. Intergrowth of phenacite and emerald from mica complexes.

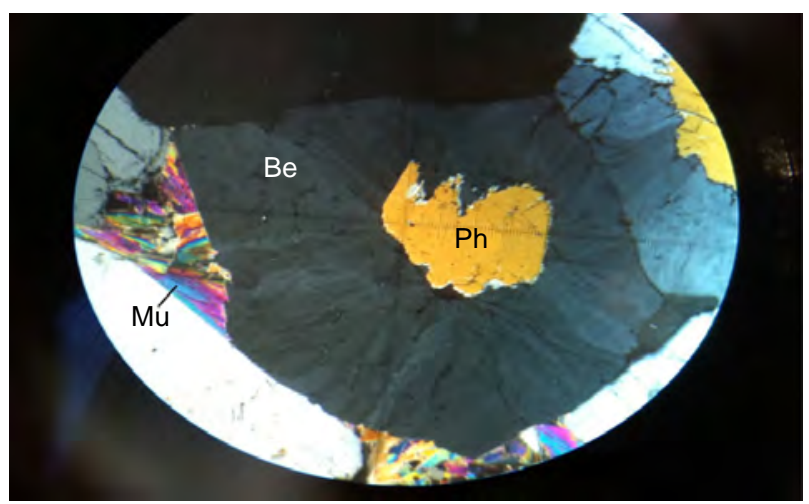

Figure 3. Inclusion of phenacite $(\mathrm{Ph})$ in beryl $(\mathrm{Be})$. Nicols are crossed. Scale $\times 80$.

ings. In 1994, in the "Yuzhny" quarry, in the lying (western) side of the ore zone of the Sretensky deposit, researchers discovered a plagioclase vein with thin phlogopite ridges, characterized by an exceptionally high (not less than $30 \%$ of the volume) concentration of large-grained (and intergrowths) phenacite. This vein belongs to a new type of ore bodies of chrysoberyl-phenacite composition, bedded in ultrabasic rocks. Unlike emerald-bearing micaceous veins that have a northwestern spread, the chrysoberyl-phenacite ore bodies are oriented in the near-latitudinal direction and have a northern incidence at an angle of $75-80^{\circ}$. The length of the veins of the new type does not exceed 5-6 $\mathrm{m}$, and their thickness varies from 20 to $50 \mathrm{~cm}$ [2]. In the vein, there are two generations of phenacite. The first is a granular, fractured

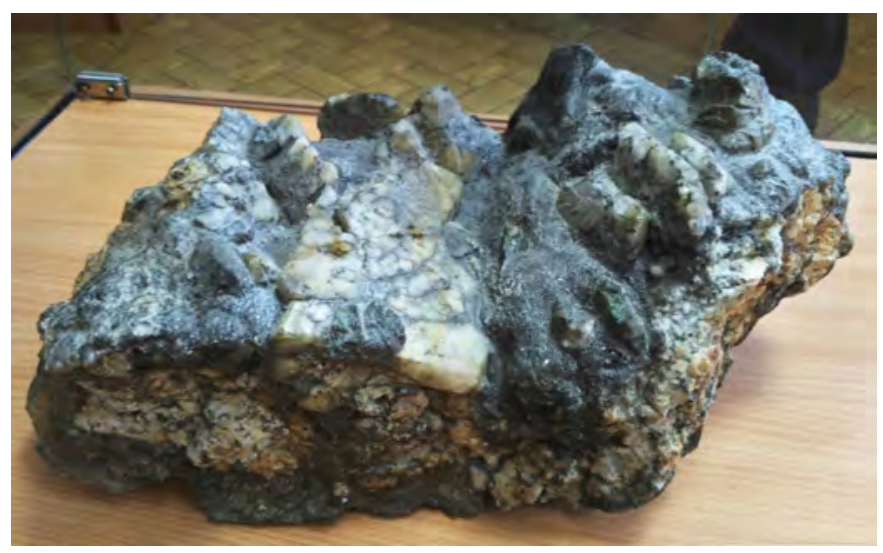

Figure 4. Crystals and splices of phenacite crystals from the Sretensky deposit.

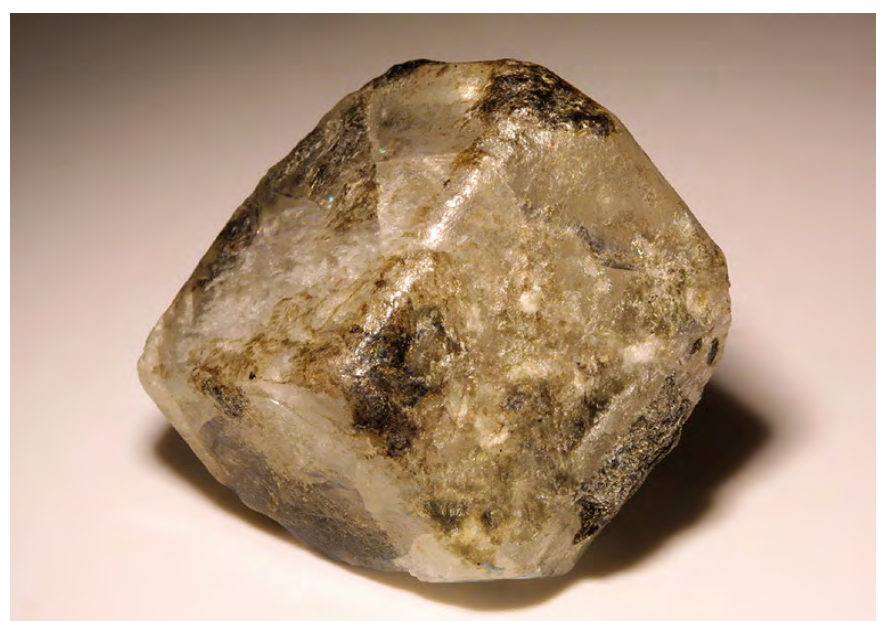

Figure 5. Phenacite crystal with rhombohedral appearance.

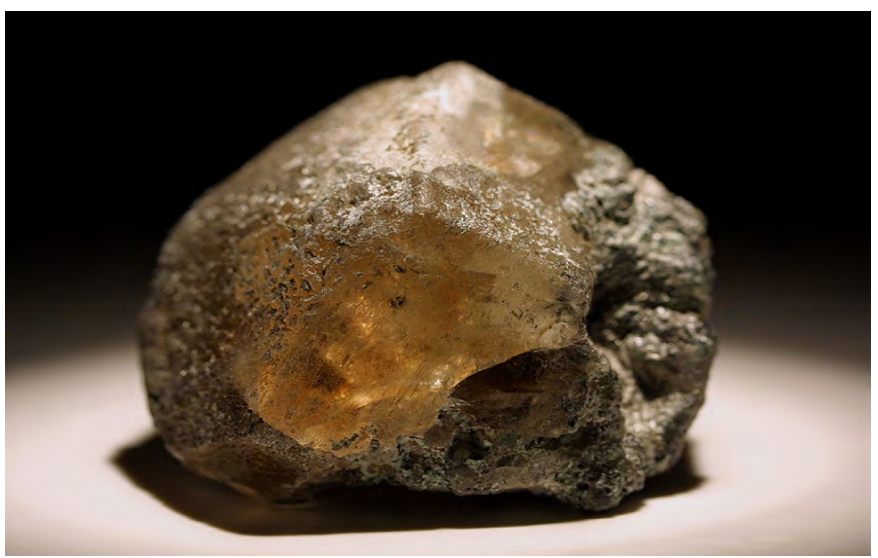

Figure 6. Crystal of wine-yellow phenacite in mica.

milk-white aggregate. The second grows on the first in the form of idiomorphic crystals (Fig. 4). The contact between them is clear smooth.

Shape of the crystals and properties of the mineral

The most common form of phenacite crystals on the Emerald Mines is rhombohedral and short columned. Crystals have a large number of faces. The usual shapes are a hexagonal prism and rhombohedrons. Twin crystals are common, druses, columnar aggregates, and spherulites are characteristic. The facets may be specular, covered with growth bumps or dissolution pits [1]. Sometimes one can observe hatching of joint growth on them (Fig. 5).

Phenacite usually is in the form of crystals grown into the rock, sometimes in the form of druses in voids. The size of crystals varies 


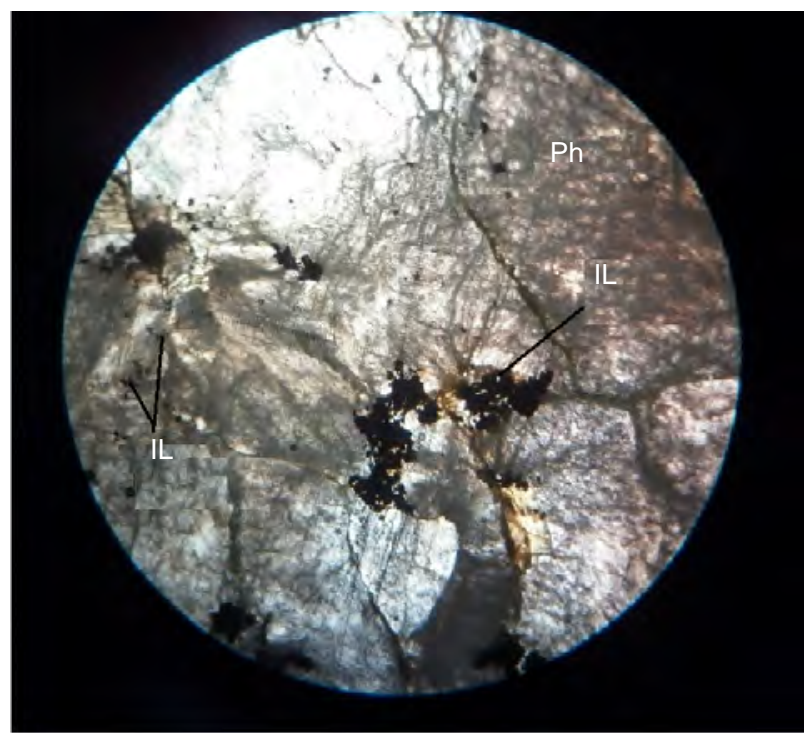

Figure 7. Plates and small dissemination of ilmenite (IL) in phenacite (Ph).

from small (fractions of $\mathrm{mm}$ ) to large (up to 10-15 cm). Individual crystals can be up to $20 \mathrm{~cm}$ in length.

Phenacite can be colorless or slightly colored in wine yellow, sometimes pinkish, light gray, white, rarely brown (Fig. 6). The color in the crystal can spread non-uniformly. Wine-yellow coloration is not stable; it completely disappears in the light.

Inclusions

Phenacite from the Ural emerald mines contains mineral, gas-liquid and mechanical inclusions that affect the transparency of the crystals.

The most frequent inclusion in phenacite is chlorite in the form of singular scales (1-6 mm) or aggregates of idiomorphic crystals, 0.6 $\times 0.5 \mathrm{~cm}$ in size. The authors present chlorite compositions in Table 1 (analyzes 3 and 4). After converting (the content of $\mathrm{H}_{2} \mathrm{O}$ is $11.65 \%$ according to the data of wet chemistry), the authors obtained the following crystallochemical formulas:

$$
\begin{gathered}
\left(\mathrm{Mg}_{3.88} \mathrm{Fe}_{0.81} \mathrm{Cr}_{0.01} \mathrm{Mn}_{0.01}\right)_{4,71} \mathrm{Al}_{1.23}\left[\mathrm{Si}_{2.79} \mathrm{Al}_{1,24} \mathrm{O}_{10}\right]\left(\mathrm{OH}_{7.76} \mathrm{~F}_{0.21}\right)_{7.97}-\text { an. } 3 . \\
\left(\mathrm{Mg}_{3.92} \mathrm{Fe}_{0.81} \mathrm{Mn}_{0.01}\right)_{4.75} \mathrm{Al}_{1.21}\left[\mathrm{Si}_{2.82} \mathrm{Al}_{1.20} \mathrm{O}_{10}\right]\left(\mathrm{OH}_{7.76} \mathrm{~F}_{0.21}\right)_{7.97}-\text { an. } 4 .
\end{gathered}
$$

By results of the analysis, it is clear that chlorite belongs to the clinochlore group.

A rather common mineral inclusion in phenacite is ilmenite, which occurs in the form of thin plates of gray-black color (Fig. 7) or small isometric inclusions. The size of the mineral is from 1-2 $\mathrm{mm}$ up to $2 \mathrm{~cm}$. One can see the compositions of the mineral in Table 1 (analyzes 1 and 2), and their recalculated crystallochemical formulas are:

$$
\begin{aligned}
& \left(\mathrm{Fe}_{0.90} \mathrm{Mg}_{0.03} \mathrm{Mn}_{0.08}\right)_{1.01} \mathrm{Ti}_{0.99} \mathrm{O}_{3}-\text { an. } 1 . \\
& \left(\mathrm{Fe}_{0.89} \mathrm{Mg}_{0.03} \mathrm{Mn}_{0.08}\right)_{1.00} \mathrm{Ti}_{0.99} \mathrm{O}_{3}-\text { an. } 2
\end{aligned}
$$

Rarely, phenacite contains pyrrhotite grains (diagnosed by X-ray diffraction), 1-2 $\mathrm{mm}$ in size. They have an irregular shape and a bronze-yellow color.

Gas-liquid inclusions in the phenacite have a tubular, isometric and elongated shape (Fig. 8). Tubular inclusions usually have sub-parallel orientation in the form of small clusters. Their dimensions do not exceed a tenth of a millimeter.

Isometric and elongated inclusions occur together. They often are oriented in the plane of healed cracks. The ratio between water and gas in the inclusions is from $3: 1$ to $5: 1$. Composition of the inclusions was mainly two-phase, with no detected three-phase inclusions.

Most phenacite crystals have numerous mechanical inclusions cracks. There are two types (Fig. 9):

- small cracks (type A) - have a strictly sustained strike, are formed due to plastic deformations when crystals are formed in a plastic medium (micaceous material); a

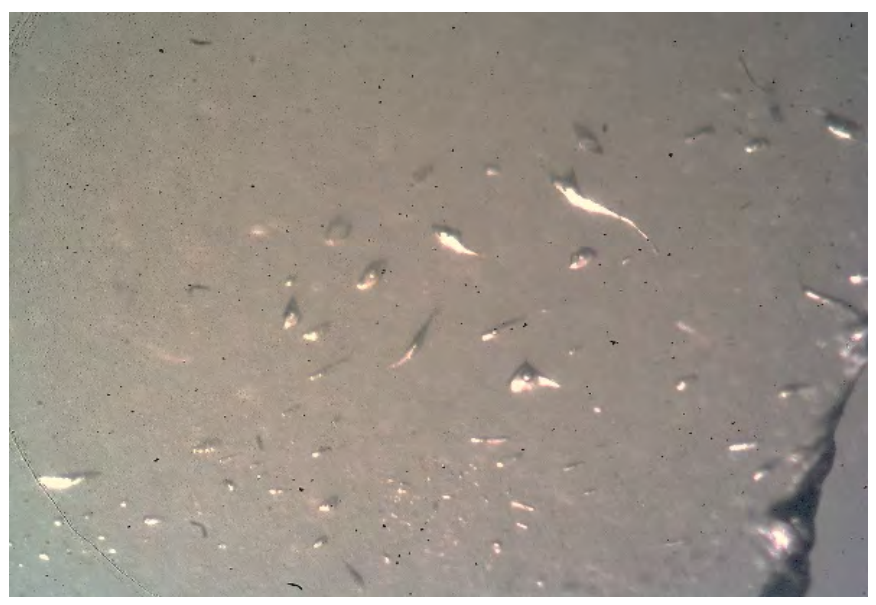

$b$

\begin{tabular}{|c|c|c|c|c|c|c|c|c|c|c|c|c|}
\hline Number & $\mathrm{SiO}_{2}$ & $\mathrm{TiO}_{2}$ & $\mathrm{Al}_{2} \mathrm{O}_{3}$ & $\mathrm{Cr}_{2} \mathrm{O}_{3}$ & $\mathrm{FeO}$ & $\mathrm{MnO}$ & $\mathrm{MgO}$ & $\mathrm{CaO}$ & $\mathrm{Na}_{2} \mathrm{O}$ & $\mathrm{K}_{2} \mathrm{O}$ & $\mathrm{F}$ & Total \\
\hline 1 & 0,01 & 52,07 & 0,00 & 0,02 & 42,38 & 3,74 & 0,74 & 0,01 & 0,00 & 0,00 & - & 98,96 \\
\hline 2 & 0,00 & 52,20 & 0,01 & 0,01 & 42,05 & 3,68 & 0,76 & 0,01 & 0,04 & 0,01 & - & 98,77 \\
\hline 3 & 27,97 & 0,02 & 21,00 & 0,12 & 9,71 & 0,11 & 26,10 & 0,02 & 0,01 & 0,02 & 0,68 & 85,76 \\
\hline 4 & 28,27 & 0,02 & 20,47 & 0,03 & 9,64 & 0,12 & 26,36 & 0,00 & 0,00 & 0,01 & 0,66 & 85,58 \\
\hline
\end{tabular}

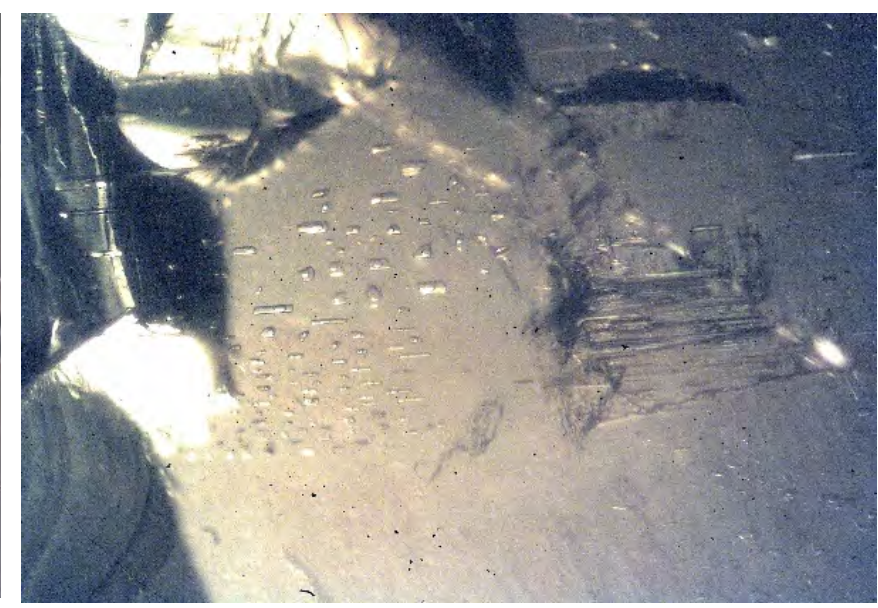

Figure 8. Planar (a) and tubular (b) gas-liquid inclusions in the phenacite of the Mariinsky deposit. Scale x70.

Table 1. Results of electron probe microanalysis of ilmenite and chlorite.

Note. Analyst: V. V. Hiller. Device: Cameca SX 100. Analysis conditions: accelerating voltage U = $10 \mathrm{kV}$, probe current I = $100 \mathrm{nA}$, probe diameter 2 um. $1,2-\mathrm{ilmen}-$ ites, 3, 4 - chlorites. 


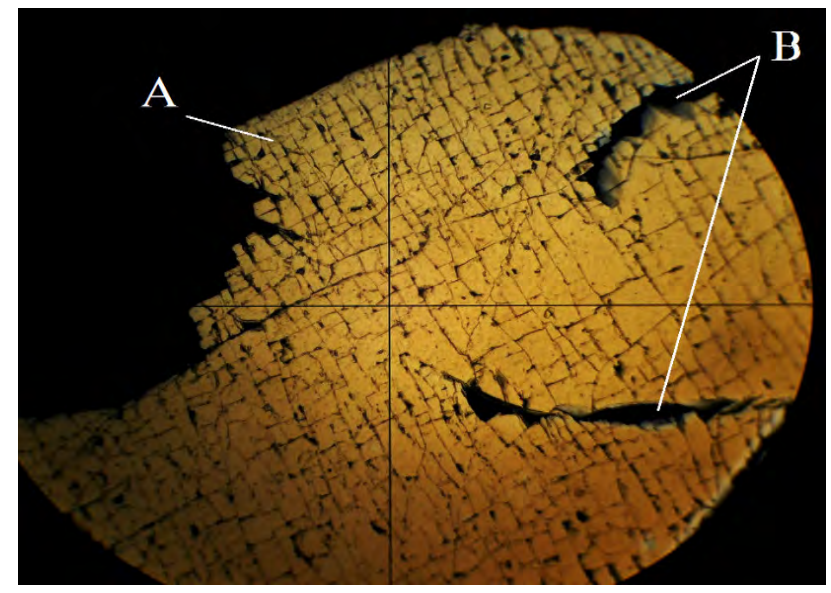

Figure 9. Cracks in the phenacite crystal. Types A and B. Nicols are crossed. Field of view $2 \mathrm{~mm}$.

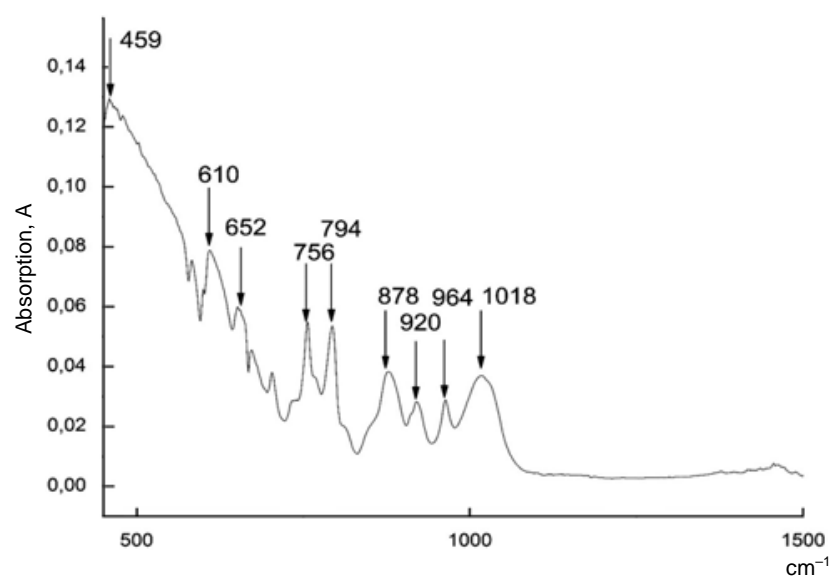

Figure 10. Reflected IR spectrum of colorless phenacite from the Mariinsky deposit.

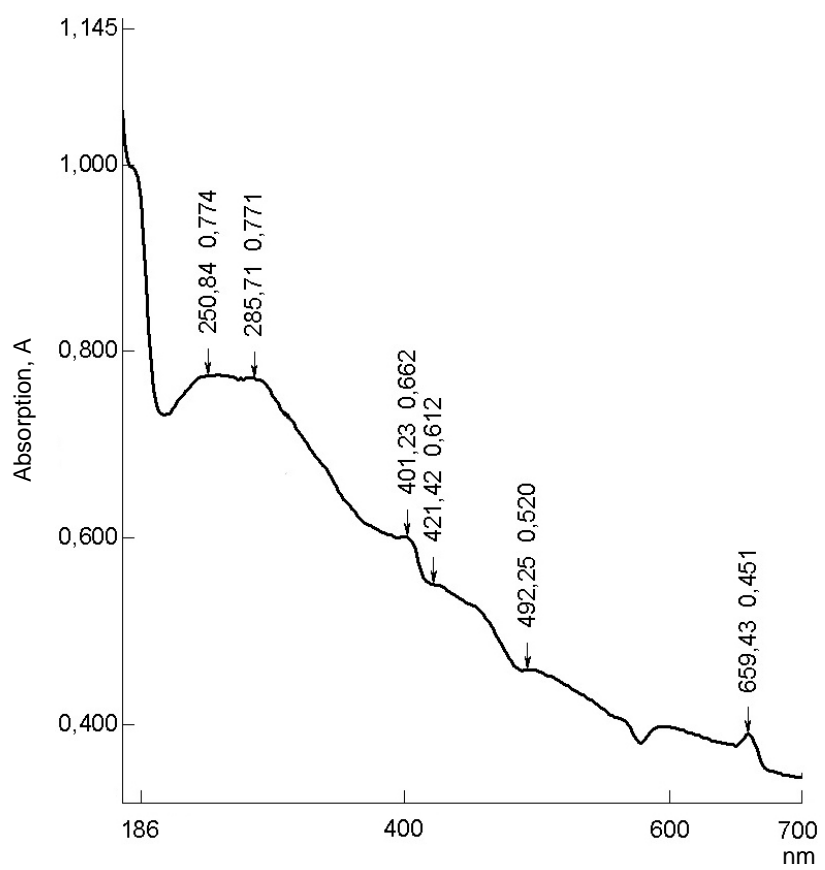

Figure 11. Optical absorption spectrum of yellow (light brown) phenacites.

- large cracks (type B) have different directions and much greater power, are formed during the extraction of crystalline raw material under the influence of impact loads.

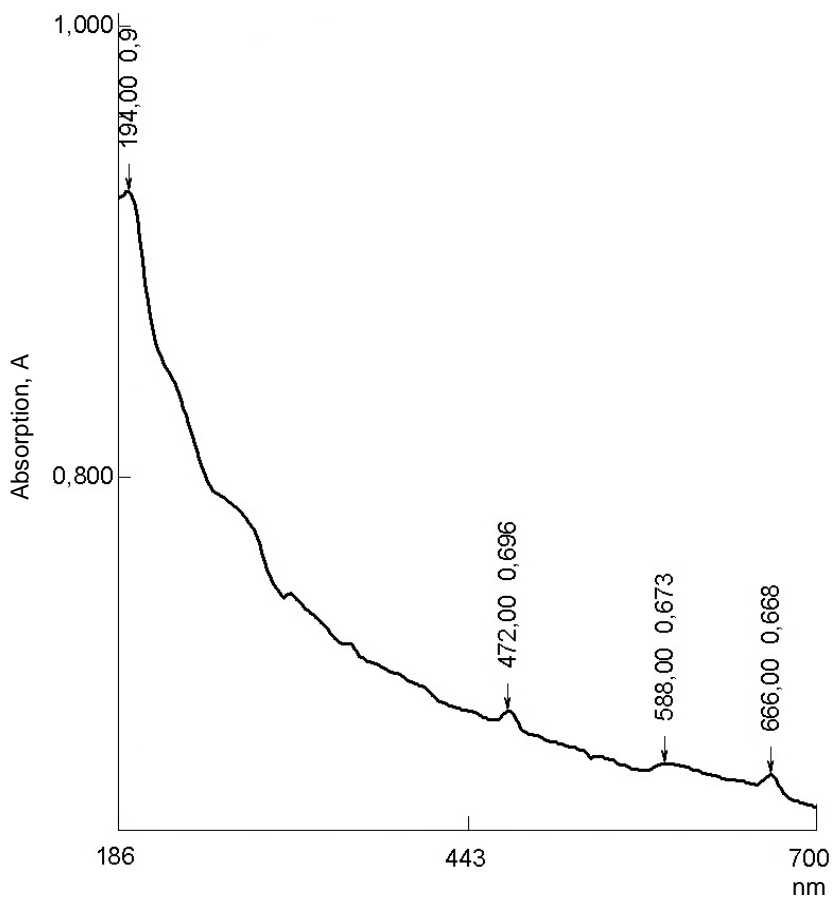

Figure 12. Optical absorption spectrum of colorless phenacites.

Formation of numerous cracks leads to a deterioration in the transparency of the phenacite crystals and formation of "blockiness". In the center of the crystal there are large transparent blocks, about $15-30 \mathrm{~mm}$ in size, and closer to the periphery, the block size decreases, leading to the decrease of transparency degree.

Infrared spectroscopy

The authors surveyed infrared spectra of phenacites from the Mariinsky deposit using a spectrophotometer "Spectrum Two perkinelmelmer", in the "reflection" mode. The shooting range was 450-4500 $\mathrm{cm}^{-1}$, the spectral resolution was $0.5 \mathrm{~cm}^{-1}$. One can see the characteristic infrared spectrum of colorless phenacite below (Fig. 10).

Weak vibrational bands of up to $660 \mathrm{~cm}^{-1}$ relate to deformation vibrations associated with $\mathrm{BeO}_{4}$ and $\mathrm{SiO}_{4}$ complexes in the phenacite structure. Bands in the range of $690-800 \mathrm{~cm}^{-1}$ relate to the valence vibrations of $\mathrm{BeO}_{4}$ complexes, and above $800 \mathrm{~cm}^{-1}$ - to $\mathrm{SiO}_{4}$ structures in the mineral [3]. For the study authors by infrared spectroscopy selected samples of colorless phenacites and phenacites having different colors, from yellow to light brown. There were no fundamental differences in the oscillation lines in infrared spectra of colorless and colored phenacite samples. The main oscillation lines of the structural complexes $\mathrm{BeO}_{4}$ and $\mathrm{SiO}_{4}$ in colorless and colored phenacites have the same wavelengths and have minor differences in the optical density. From this, we can draw the following conclusions: the coloring of phenacites has an electron-hole nature, and, due to it, the color appearance mechanism does not affect the symmetry of local structural units in the crystal structure of the mineral.

Optical spectroscopy

The authors recorded optical absorption spectra on a specialized SHIMADZU UV-3600 spectrophotometer in the wavelength range of 185-3300 nm, at room temperature. The authors obtained optical absorption spectra of colorless and light brown phenacite from the Mariinsky deposit. On both spectra of the mineral in the range of 2900-3200 nm are oscillations associated with the presence of $\mathrm{OH}$ group. There are peaks in the range of phenacites of yellow color in the interval of 250-286 nm (Fig. 11).

In the transparent colorless phenacites, there was no absorption in ultraviolet range (Fig. 12). Other low-intensity absorption bands in optical spectra are noises related to the survey conditions. 
Table 2. Comparison of gemmological characteristics of phenacite from different countries.

\begin{tabular}{lccc}
\hline Characteristics & Brazil & Sri Lanka & $\begin{array}{c}\text { Russia } \\
\text { (Emerald Mines) }\end{array}$ \\
\hline Refractive index & $1,650-1,665$ & $1,651-1,668$ & $1,651-1,668$ \\
Birefringence & 0,015 & 0,17 & 0,017 \\
Shine & Vitreous & Vitreous & Vitreous \\
Density $\left(\mathrm{g} / \mathrm{cm}^{3}\right)$ & 2,97 & 2,97 & 2,97 \\
Fluorescence: & & Very weak & Very weak green, \\
LWUV & No & green, uniform & uniform \\
SWUV & No & No & No \\
\hline
\end{tabular}

The nature of the phenacites coloration currently is not studied in detail in optical adsorption spectroscopy. Many authors agree on only one thing, that the nature of coloration is associated with electron-hole centers. Disappearance of color in phenacite upon expose to either ultraviolet radiation or high temperatures indicates it. According to one of the theories, these absorption lines are associated with the oxygen vacancies that have captured an electron [4]. Other researchers believe that these absorption lines are associated with bridged electron centers of the $\mathrm{Al}^{3+}-\mathrm{O}^{-}-\mathrm{Al}^{3+}$ type [4]. They are formed due to the isomorphic occurrence of aluminum ions in the crystal lattice of phenacite, in an amount up to $0.5 \%$ [5]. In addition, the presence of paramagnetic centers affects the color in phenacites, and many works were devoted to studying these paramagnetic centers in the mineral [6-10]. Thus, during the study on the EPR spectra of the impurity radical $\left[\mathrm{PO}_{4}\right]^{4-}$ in the light brown phenacite from the Volynsky deposit [7], researchers observed a difference in the intensity of the lines of three magnetically nonequivalent centers. Dissymmetrization of crystals, as a result of the uneven distribution of point defects in the process of crystal growth, is a widespread phenomenon, for example, dissymmetrization of properties in barite [11].

Gemmology

Phenacite as a precious stone is quite rare in the modern jewelry market. Color differences (pink and wine-yellow) are still popular, but due to the rapid fading in the sunlight, do not have much demand in jewelry stores. Due to a sufficiently high refractive index (higher than that of topaz, beryl, tourmaline) it was of interest in the Urals in a role of an "Ural diamond", before diamonds finding. Current works aim to strengthen and fixate the color in the phenacite.

Currently, the world jewelry market receives phenacite mainly from Brazil and Sri Lanka (see Table 2).

From the materials provided one can see that the gemmological characteristics of the phenacites from the Ural Emerald Mines are similar to the characteristics of the phenacites from Sri Lanka. They have similar formation conditions.

\section{REFERENCES}

1. Popov M. P. 2014, Geologo-mineralogicheskie osobennosti redkometal'noy mineralizatsii $v$ Vostochnom ekzokontakte Aduyskogo massiva $v$ predelakh Ural'skoy izumrudonosnoy polosy [Geological and mineralogical features of rare metal mineralization in the Eastern exoconface of the Aduisk Massif within the Ural Emerald Strip], Ekaterinburg, 136 p.

2. Zolotukhin F. F., Zhernakov V. I, Popov M. P. 2004, Geologiya i zakonomernosti raspredeleniya dragotsennykh kamney Malyshevskogo mestorozhdeniya (Ural'skie Izumrudnye kopi) [Geology and regularities of distribution of precious stones of Malyshevsky deposit (Ural Emerald Mine)], Ekaterinburg, $75 \mathrm{p}$.

3. Plyusnina I. I. 1967, Infrakrasnye spektry silikatov [Infrared spectra of silicates], Moscow, $190 \mathrm{p}$.

4. Lozykowski H., Holuj F. 1969, Luminescence in Phenacite. The journal of chemical physics, vol. 51, no. 15, pp. 2315-2321.

5. Novozhilov A. I., Samoilovich M. I., Karachkovskaya A. N. 1970, Electron paramagnetic resonance in irradiated phenacite Be2SiO4. Journal of Structural Chemistry, vol. 11, pp. 393-396.

6. Guseva V. B., Zatsepin A. F., Vazhenin V. A., Artemov M. Yu., Kukharenko A. I. 2010, Paramagnitnye defekty $v$ neytronno-obluchennykh kristallakh fenakita [Paramagnetic defects in neutron-irradiated phenacite crystals]. Fizika tverdogo tela [Physics of the Solid State], vol. 52, no. 4, pp. 643-650.

7. Evgrafova L. A., Gaynullina N. M., Nizamutdinov N. M., Vinokurov V. M. 1972 O prirode elektronnogo i dyrochnykh tsentrov $v$ monokristalle fenakita [On the nature of electron and hole centers in a phenacite single crystal]. Fizika mineralov [Physics of minerals], vol. 11, pp. 14.

8. DuVarney R. C., Garrison A. K. 1978, An EPR-ENDOR study of phosphorus in phenacite. J. Chem. Phys. vol. 88(12), pp. 5342-5347.

9. Symons M. C. R. 1970, EPR study of phenecite: the $P O_{4}$ radical. J. Chem. Phys. vol. 53(12), pp. 857-858.

10. Platonov A. N. 1976, Priroda okraski mineralov [Nature of coloring of minerals], Kiev, 264 p.

11. Khasanov R. A., Nizamutdinov N. M., Khasanova N. M., Vinokurov V. M. Morozov G. S., Krivtsov A. O. 2012, Derivation of the conditions for equivalent positions in crystals: The dissymmetrization of barite by electron spin resonance spectra. Crystallography Reports, vol. 57, no. 5, pp. 751-757.
Михаил Петрович Попов, popovm1@yandex.ru Институт геологии и геохимии

им. академика А. Н. Заварицкого УрО РАН

Россия, Екатеринбург, ул. Академика Вонсовского, 15

Анатолий Германович Николаев,

Anatolij-nikolaev@yandex.ru

Казанский (Приволжский) федеральный университет

Россия, Казань, ул. Кремлевская, 18

\section{Mikhail Petrovich Popov,}

popovm1@yandex.ru

Zavaritsky Institute of Geology and Geochemistry

of the Ural Branch of the Russian Academy of Sciences

Ekaterinburg, Russia

Anatoliy Germanovich Nikolaev,

Anatolij-nikolaev@yandex.ru

Kazan' (Volga region) Federal University

Kazan', Russia 